\title{
Job Insecurity, Organizational Commitment, Financial Responsibility, and Turnover Intention, a Test of Three-Way Interaction
}

\author{
Faris Alghamdi ${ }^{1}$ \\ ${ }^{1}$ Business School, Albaha University, Albaha, Saudi Arabia \\ Correspondence: Faris Alghamdi, Business School, Albaha University, Albaha, Saudi Arabia.
}

Received: April 7, 2018

doi:10.5539/ibr.v11n6p213

Accepted: April 26, $2018 \quad$ Online Published: May 25, 2018

URL: https://doi.org/10.5539/ibr.v11n6p213

\begin{abstract}
Job insecurity as a hindrance stressor has a negative effect on behavioral outcomes. The current study investigates the association between job insecurity and turnover intention among fixed-contract employees in Albaha province, Saudi Arabia. Additionally, it examines the moderator role of organizational commitment and financial responsibility in the association between job insecurity and turnover intention. 105 fixed- contract employees working in pubic organizations participated in the study. Pearson correlation analysis and hierarchical regression analysis revealed that job insecurity was positively and significantly related to turnover intention, as well as job insecurity, organizational commitment and financial responsibility interact in the predication of turnover intention (3-way interaction).
\end{abstract}

Keywords: job insecurity, organizational commitment, financial responsibility, turnover intention

\section{Introduction}

Job insecurity is a work stressor that scores among the most prominent psychological risks at the workplace. Comparing to unemployment, job insecurity can equal and sometimes even surpass the effect of unemployment (De Witte, Pienaar, and De cuyper, 2016; Leka and Jain, 2010; De Witte, 1999). It is a stressful experience aggravated by increasing in global competition, fast technological development, conflicts in the Middle East, and economic recession, i.e. lower oil prices. Theory of job adaptation explained that employees would seek out to relieve job dissatisfaction through different job adaptation responses, for instance, withdrawing themselves from the stressors (Hulin, 1991). Nowadays, the likelihood of losing one's job is a very big concern for many temporary or contract employees (Låstad, Elst, and De Witte, 2016; Greenhalgh and Rosenblatt, 2010; Lübke and Erlinghagen, 2014).

It was estimated that $59 \%$ of the Saudi population is younger than 29 years old. The unemployment rate in 20 to 29 age bracket remains high at more than $39 \%$ in 2015. According to Saudi Arabia Labor Market Report (2016), Saudi rapid economic growth, cultural traditions, and young population generate five specific challenges, namely the lack of competitive and fulfilling private sector jobs, the reliance on foreign labor, high youth unemployment, inefficient job matching, and the low rate of female participation in the workforce. These critical labor market conditions seem to be linked to a higher fear of losing one's job, a higher experience of stress, and negative work-related outcomes (Jiménez, Milfelner, Zizek, and Dunkl, 2017; Anderson and Pontusson, 2007). A meta-analysis on the association between job insecurity and possible outcomes revealed that job insecurity is related to negative consequences for both employees and employers, together with short- and long-term effects. For employees, job insecurity is linked to poorer mental and physical health, lower satisfaction, and lower job involvement. For employers, it is associated with stronger turnover intentions and less organizational commitment (Låstad, Elst, and De Witte, 2016; Cheng and Chan, 2008; Sverke, Hellgren and Naswall, 2002). According to General Authority for Statistics, Saudi Labor Market Report showed that a total of 53, 997 mass layoffs events occurred in the third quarter of 2017. All these factors have led to a heightened sense of job insecurity among Saudi workforce, yet no empirical studies regarding the impact of job insecurity and its potential job-related consequences have been conducted in the context of Saudi Arabia, particularly in southern region. Moreover, Lee and Jeong (2017) claimed that even though scholars have documented the relationship between job insecurity and employee attitude toward the organization and between job insecurity and mental/ physical health, less is known about the relationship between job insecurity and behavioral outcomes such as turnover intention. They emphasized that few researchers have examined the relationship between job insecurity 
and turnover intention outside of Western countries (Hur and Perry, 2014).

In response to these challenges, the main aim of current study is to investigate the association between job insecurity and turnover intention among fixed-contract employees in Albaha province, Saudi Arabia. Additionally, it examines the moderator role of organizational commitment and financial responsibility in the association between job insecurity and turnover intention.

\section{Literature Review}

\subsection{Job Insecurity}

Researchers have studies widely the construct of job insecurity and its consequences, yet many different definitions of job insecurity exist in the literature. In their seminal study, Greenhalgh and Rosenblatt (1984) defined job insecurity as a "perceived powerlessness to maintain desired continuity in a threatened job situation" (p. 438), while Vuuren, Klandermans, Jacobson, and Hartley (1991). defined it as a "discrepancy between the level of security a person experiences and the level she or he might prefer" (p. 7). That is, it is a difference between the preferred the perceived level of security at workplace settings, such that threat of job loss are perceived by employees, and therefore worry about it.

Scholars have conceptualized job insecurity utilizing different dimensions such as objective-subjective (De Witte and Näswall, 2003), cognitive-affective (Pienaar, De Witte, Hellgren, and Sverke, 2013), and quantitative-qualitative (Hellgren, Sverke, and Isaksson, 1999). Given that, Erlinghagen (2008) and Jiménez et al. (2017) explained that subjective insecurity is the individual subjective feeling of insecurity about keeping the job in the future, whereas objective insecurity is the consequence of economic situations that may impact the perception of individuals regarding job insecurity. Borg and Elizur (1992) linked cognitive insecurity to the possibility of losing one's job, and linked affective insecurity to the fear of losing one's job. Shoss (2017) defines job insecurity as "a perceived threat to the continuity and stability of employment as it is currently experienced"(p. 1914). He, therefore, differentiated between two types of job insecurity, namely quantitative and qualitative. The former refers to perceived threats to the job itself, while the latter refers to perceived threats to features of the job, involving the loss of job privileges such as pay raise and promotion.

\section{Focus of reaction}

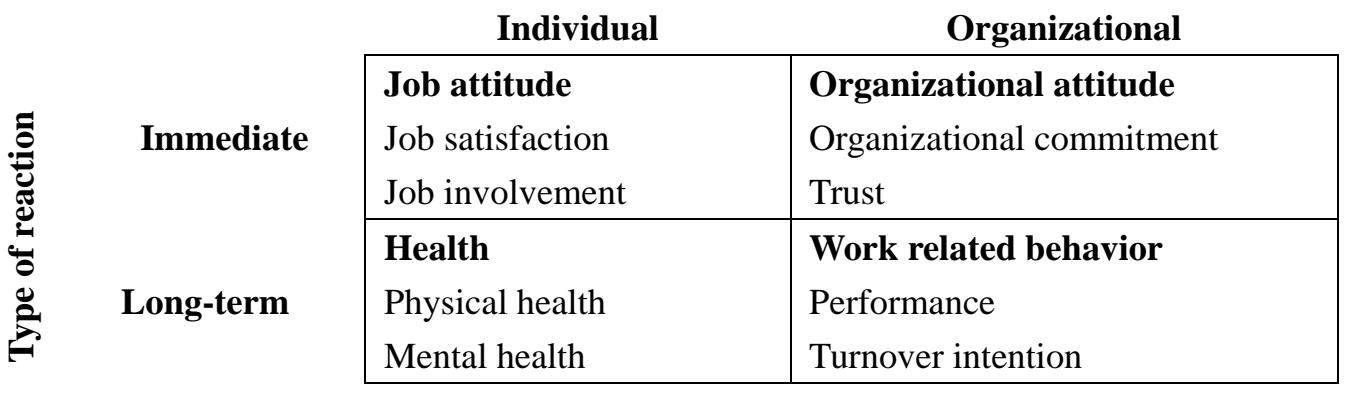

Figure 1. Types of consequences of job insecurity. Adapted from "No security: A Meta-Analysis and Review of Job Insecurity and Its Consequences", by Sverke, M., Hellgren, J., and Näswall, K., (2002), Journal of Occupational Health Psychology, 7, p. 244.

Sverke, Hellgren, and Naswall $(2002,2006)$ argued that the followings consequences are as a function of job insecurity: frustration and stress that occurs when someone feels his needs threatened by a perceived insecure employment condition, stress reactions are due to uncertainty and ambiguity about a job, health-related consequences such as psychosomatic symptoms, attitudinal consequences such as job satisfaction, and behavioral consequences that happens when employees feel insecure about their job's condition. The last consequence may lead employees to leave an organization. Finally, these consequences can be categorized as presented in Fig. 1 in terms of immediate or long-term reactions, and whether the focus of reaction is at an individual level or an organizational level.

\subsection{Turnover Intention}

Turnover intention is a key concern for leaders and managers across organizations. It can seriously damage workplace morale, prevent employees from developing any commitment or identification towards their organizations, and reduce job satisfaction (Lin, Tsai, and Mahtma, 2017; Lutgen-Sandvik, Hood, and Jacobson, 2016). Turnover intention is a deliberate and conscious willfulness of employees to leave an organization within a predictable future (Ertureten, Cemalcilar, and Aycan, 2013). The conservation of resource theory postulated 
that when employees do not have enough resources to effectively deal with job related issues, their long-term effect of anxiety and pressure may be developed and enhanced (Houkes, Janssen, Jonge, and Bakker, 2003). Stress theory (Lazarus and Folkman, 1984) is complementary to the pervious theory, explaining that a state of emotional or psychological strain such as anxiety and pressure can substantially trigger turnover intention.

Researchers pointed out that turnover intention is an accurate predictor for actual turnover. Employee decisions to quit are typically deemed and made with respect to their present job satiation. It argued that an intention gives a better explanation for the actual turnover and a clear idea regarding employee perception about turnover (Gregory, Way, LeFort, Barrett, and Parfrey, 2007; Mowday, Steers, and Porter, 1979). Mobley's (1977) intermediate linkages model delineated the steps to turnover - the psychological process: job dissatisfaction, thinking of quitting, assessing of job seeking/expected utility and costs of quitting, intention to search for alternative, search for alternative, assessing for alternative, comparison of alternative against current job, and finally decision to be made to quit or stay.

Having individual nature of psychological processes, it is, according to this model, not necessary to follow the steps in sequence, and it may miss steps as a whole. The significance of the model in question is the identification of the behavioral process that goes form dissatisfaction to turnover. Turnover intention can be voluntary or involuntary. The former can exist when employees make a decision to leave at their discretion. It often happens when employees recognize another opportunity that is better than their existing position, have to leave for health or family reasons, and/or plan to voluntarily retire. On the other hand, the latter occurs when an organization deices to remove an employee from a position. This is more likely to happen when an organization is not happy with an employee job performance, productivity, and/or behavior, hence fire him or her. It may also occur when an organization change strategy and process, and undergo mergers and acquisition, as well as restructure or downsize, due to, for instance, economic factors (Çınar, Karcıoğlu, and Aslan, 2014).

\subsection{Organizational Commitment}

Organizational commitment is a complex and multifaceted construct. It is a positive attitude of employees representing a significant determinant of employee retention, leading to a psychological connection and identification with an organization (Meyer, Allen, and Smith, 1993; Vujičić et al., 2015). Three-component model of organizational commitment (Meyer and Allen, 1991) has received by far the most attention (Culpepper, 2011; Meyer, Stanley, Herscovitch, and Topolinytsky, 2002; Solinger, van Olffen, and Roe, 2008). They identified three distinct components, namely commitment as an affective attachment to the organization, commitment as a perceived cost related to leave the organization, and commitment as an obligation to remain in the organization (Meyer, Allen, and Smith, 1993).

Affective commitment (desire-based) is defined as how much employees identify with, are involved in, and enjoy relationship in an organization. Continuous commitment (cost-based) is as a result of perceived leaving cost or side-bets as mentioned in Becker's (1960) side-bet theory. Normative commitment (obligation-based) is a feeling of employees of obligation to remain in an organization, thinking that it is the right and morel thing to do. It is argued that these three components are likely to develop in various ways and have various implications for job behavior. Affective commitment, for instance, was likely to be mostly sensitive to work experiences. Continuance commitment was likely to develop in response to conditions that rise the cost to leave an organization. Normative commitment was supposed to develop in response to social pressure. Finally, employees who have a strong affective commitment stay with an organization because they want to, employees who have a strong continuance commitment stay with an organization because they need to, and employees who have a strong normative commitment stay with an organization because they believe they should do so ( Powell and Meyer, 2004; Meyer, Allen, and Smith, 1993).

\section{Hypothesis Development}

Most presented research on job insecurity has concentrated on its negative consequences on employees and organizations alike. Attitudinal reactions, i.e. turnover intention, reduced organizational commitment, and reduced satisfaction are related to job insecurity. Moreover, negative effects on family interactions (e.g., household income) have been reported. As such, theory of job adaptation (Hulin, 1991) postulated that employees are likely to mitigate job dissatisfaction through different job adaptation responses. For example, employees might withdraw themselves from the stressor through being less satisfied with the job and less committed to the organization, hence having a stronger intention to quit the job (Davy, Kinicki, Scheck, 1997; Probst, 2000, 2002; Cheng and Chan, 2008). The model of conservation of resources (Hobfoll, 1989) posited that employees strive to reduce loss of resources due to stress, end hence when they fear that they may lose their job, one option employees may take to lessen this risk is to search for and accept a new job that provide a higher 
level of job security. This situation of a high level of job insecurity was manifested in longitudinal study over 1 year (Blau, 2007). Employees turnover intention associated with their job search activity, hence explained through job insecurity. In the same vein, job search and voluntary turnover model (Direnzo and Greenhaus, 2011) suggested that employees perform job searches so as to increase their career chances, career competences, employability, and to be ready for job loss during times of high job insecurity ( Tschopp and Grote, 2014; Lebert and Voorpostel, 2016).

Social exchange theory (Blau, 1964) explained the norm of reciprocity between employer and employees, in which the former party provides support to the latter party as to job security in return for its identification, loyalty, and commitment to an organization. When an organization undergo some organizational strategies such as restructuring, downsizing, and reengineering, employees are more likely to perceive that long-term job security is threatened. Likewise, the mainstream of occupational stress models claimed that stressors occupational settings produce negative changes in employees, physical, psychological, and behavioral aspects (Beehr, 1995; Lee and Jeong, 2017; Adebayo, 2006). Having said that, employees perceived job insecurity arising from a workplace setting feel that a given organization does not treat them well. Hence, they may respond through showing more negative attitudes including less organizational commitment.

Podsakoff, LePine and LePine (2007) conducted a meta analysis study with 183 independent samples and confirmed that job insecurity considers a hindrance stressor since it is directly linked to increased levels of job and organizational withdrawal. Employees feel insecure about the future and continuance of their job will lead to lower organizational commitment, and hence quit the job. Applying job demands resources model (Schaufeli and Taris, 2014), it found that job insecurity had a direct and an indirect effect, by burnout, on organizational commitment and turnover intention (Hu and Schaufeli, 2011; Schaufeli, 2016).

Sinclair and Cheung (2016) explained that direct measures capture economic deprivation via an assessment of one's total income i.e., either from annual salary or one's total household income. Riggotti, Mohr, and Isaksson (2015) found that financial responsibility strengthened the negative association between job insecurity and organizational commitment. Rosenblatt, Talmud, and Ruvio (1999) argued that male-breadwinner made male more vulnerable then female to job loss because female may not consider financial matters to be their main responsibility.

Lebert and Voorpostel (2016) claimed that the household's financial situation impacts employee career decisions. In their study, they concluded that economic hardship increased probabilities of voluntary turnover. Some scholars argued that spouses are responding to their partner's job loss through increasing their own participation in paid work (Starr, 2014). Career decisions are not taken in isolation, hence depending to a varying degree of the household situation. Sora, Caballer, and Peiró (2010) conducted a study in Spain on 942 employees and concluded that job insecurity associated negatively to organizational commitment and positively to turnover intention. Moreover, the interaction between economic need ( responsibility) and job insecurity predict organizational commitment and turnover intention, such that employees who perceive job insecurity and experience high job dependence will have lower organizational commitment and a stronger intention to leave the organization. Finally, Chirumbolo and Areni (2005) undertaken an empirical study on 425 employees to examine the impact of job insecurity on two indicators of organizational behavior, i.e. job performance and absenteeism, and the moderator role of job satisfaction and organizational commitment. The results showed that job insecurity was negatively associated with work related behavior, i.e., job performance and positively with absenteeism; nevertheless job attitude, i.e. job satisfaction and organizational attitude, i.e. organizational commitment moderated only the effect of job insecurity on job performance. They argued that higher levels of job satisfaction and organizational commitment moderate the effects of job insecurity on the long term organizational consequences. Based on the discussion above, the first hypotheses are formulated:

H1: there is a significant negative correlation between job insecurity and organizational commitment.

H2: there is a significant positive correlation between job insecurity and turnover intention.

H3: there will be three-way interaction between financial responsibility, organizational commitment, and job insecurity in predicting turnover intention, such that employees who feel less commitment to the organization, experience high financial responsibility, and perceive high job insecurity will have a stronger intention to leave the organization.

\section{Method}

\subsection{Participants and Procedure}

Data were collected in 2017 from a sample of employees with fixed-term contract working in public 
organizations in Albaha province. The questionnaire was distributed in paper form accompanying by a cover letter illuminating the aim of the study and an assurance of confidentiality and anonymity. In the letter, there were instructions for completing and handing back the questionnaire to the principal researcher within two weeks. Excepting demographic variables, the questionnaire was translated from English language to Arabic language, which is the official language for all potential subjects, using a back-translation technique (Werner and Campbell, 1970). Hence, a professor at Albaha university translated the original questionnaire into Arabic language and then another professor at the same university translated back to English language without references to the original English version. Both professors are fully bilingual. After that, the researcher went carefully over both versions and made revisions necessary for ensuring a complete and accurate meaning of the original text of the questionnaire, which, in turn, enhancing ease of use, readability, and an appropriate level of formality.

The present study applied a self-report questionnaire administered to 115 employees on a fixed-term contract at the end of November 2017. Of the distributed questionnaires, 105 responses were received and useful for analysis, with a response rate of $91 \%$. There were 57 male in the sample (54.3\%) and 48 female (45.7\%). The majority of respondents (45.7\%) were in the range from 29-39 years old, and most of respondents $(56.2 \%)$ received a bachelor's degree. Finally, majority of respondents (40\%) had family members of 4 and above. Table 1 shows the demographic composition of the respondents.

Table 1. Demographic variables of the respondents $(\mathrm{N}=105)$

\begin{tabular}{llll}
\hline Variable & Category & Number of respondents & Percentage \\
\hline Gender & Male & 57 & 54.3 \\
& Female & 48 & 45.7 \\
Age & $18-28$ & 41 & 39 \\
& $29-39$ & 48 & 45.7 \\
& $40-50$ & 15 & 14.3 \\
Education & $>50$ & 1 & 1 \\
& Less than high school & 12 & 11.4 \\
& High school & 23 & 21.9 \\
Family members & Undergraduate & 59 & 56.2 \\
& Graduate & 11 & 10.5 \\
& 1 & 23 & 21.9 \\
& 2 & 12 & 11.4 \\
& 3 & 10 & 9.5 \\
& 4 & 18 & 17.1
\end{tabular}

\section{Measures}

The current study utilized a descriptive cross-sectional design. The survey used in this study is structured, self-administered, and consists of four parts. The first part included items regarding demographic characteristics of participants, namely age, gender, educational level, and number of family members. Participants reported their age in years, their gender $(0=$ female and $1=$ male $)$, educational level $(1=$ less than high school, $2=$ high school, $3=$ undergraduate, $4=$ graduate), and number of family members $(1=1,2=2,3=3,4=4,5=$ more than four members).

The second part includes job insecurity and financial responsibility variables. The former was measured using the Job Insecurity Scale (JIS). This scale includes 4-item originally coined by De Witti (2000). One of these items was reveres coded, hence using computer command in SPSS to transform data before running the analyses. Participants were asked to rate theses items on a 5-point Likert type scale, ranging from 1 ( strongly disagree) to 5 (strongly agree). Cronbach's alphas for this scale in the current study were .72. The later was measured using the question developed by (Hoffmeyer-Zlotnik and Warner, 1998). The question is "what is your contribution to the household's income?". Partcpaintas were asked to choose one of the following potential responses: sole earner $(100 \%)$, main earner $(>50 \%)$, joint earner $(\approx 50 \%)$, and contributory earner $(<50 \%)$.

The third part is organizational commitment which was measured a set of four items developed by Cook and Wall (1980). These items have been used to assess affective commitment ( desire-based) which is defined as how much employees identify with, are involved in, and enjoy relationship in an organization (Meyer and Allen, 1991). Participants were asked to rate theses items on a 5-point Likert type scale, ranging from 1 ( strongly disagree) to 5 (strongly agree). Cronbach's alphas for this scale in the current study were .78 .

The last part is turnover intention. It is measured with the scaled coined by Cammann, Fichman, Jenkins, and Klesh (1979), including three items planed to measure employees' tendency to quit the job in the near future. Participants were asked to rate theses items on a 5-point Likert type scale, ranging from 1 ( strongly disagree) to 
5 (strongly agree). Cronbach's alphas for this scale in the current study were .74 .

\section{Data Analysis}

Preliminary analyses of the data were descriptive statistic ( means, standard deviations) along with correlations of study variables, as shown in Table 2. Next, hierarchical multiple regression analysis was carried out to examine study hypotheses. Based on Cohen and Cohen (1983), variables of lower order were introduced first, and the higher order terms later. Hence, control variables were entered in first step (gender, age, educational level, and family members) followed by predictor variables (job insecurity, organizational commitment, and financial responsibility). In step 3, second-order interaction terms, i.e. all possible pairs of three predictors (job insecurity , organizational commitment, and financial responsibility) were entered. In the last step, the three -way product (job insecurity $\times$ organizational commitment $\times$ financial responsibility) was introduced. It should be noted that predictor and moderator variables were centered so that possible problem of multicollinearity can be solved, as well as interpretability can be maximized (Wu and Zumbo, 2008). Graphical representation was plotted to visualize the nature of interactions by means of the Excel sheet provided by Dawson and Richter (2006).

\section{Result}

Table 2. shows an overview of correlations between all variables included in the further analyses and main descriptive statistics.

Table 2. Means, standard deviations, and correlations among variables ( $N=105)$

\begin{tabular}{ccccccccc}
\hline & Mean & SD & 1 & 2 & 3 & 4 & 5 & 6 \\
\hline Age & 1.8 & .72 & & & & & & \\
Edu & 2.7 & .82 & -.07 & & & & & \\
Gen & .54 & .50 & -.13 & -.11 & & & & \\
FiR & 2.3 & 1.1 & $-.20^{*}$ & -.00 & .10 & & & \\
FaM & 3.4 & 1.6 & .08 & .04 & .04 & .18 & & \\
JoI & 3.6 & .74 & -.01 & -.04 & -.15 & -.11 & $-.33^{* *}$ & .14 \\
OrC & 4.4 & .63 & .10 & .05 & -.19 & -.14 & .08 & $.33^{* *}$ \\
TuI & 2.5 & 1.1 & -.12 & -.06 & -.05 & $.22^{*}$ & $-.36^{* *}$ & $-.36^{* * *}$ \\
\hline
\end{tabular}

Note. Age= age in years; $\mathrm{Edu}=$ education; Gen= gender; $\mathrm{FiR}=$ financial responsibility; $\mathrm{FaM}=$ family members; $\mathrm{JoI}=$ job insecurity; $\mathrm{OrC}=$ organizational commitment; TuI= turnover intention.

$* P<05 ; * * P<01,2$-tailed significance.

Financial responsibility associated negatively and significantly with age $(\mathrm{r}=-.20, P<.05)$. Family member related positively and significantly to job insecurity $(\mathrm{r}=033, P<.01)$. Lastly, turnover intention related positively and significantly to financial responsibility $(\mathrm{r}=022, P<.05)$ and job insecurity $(\mathrm{r}=033, P<.01)$, as well as related negatively and significantly to family member $(\mathrm{r}=-036, P<.01)$ and organizational commitment $(\mathrm{r}=-036$, $P<.01$ ). Given that, hypothesis 1 stating that there is a significant negative correlation between job insecurity and organizational commitment has no initial support. Nevertheless, the positive and significant relationship found between job insecurity and turnover intention provides initial support for hypothesis 2 .

In order to test study hypotheses, Pearson correlation analysis and hierarchical multiple regression analysis were carried out. Confirming the initial results, Pearson correlation analysis revealed that there was no significant negative correlation between job insecurity and organizational commitment $(\beta=.14, P>.05)$. Therefore, hypothesis 1 was not supported. As for hypothesis 2 , the result of Pearson correlation analysis indicated that there was a significant positive correlation between job insecurity and turnover intention $(\beta=.33, P<.01)$. Therefore, hypothesis 2 was supported.

Finally, hierarchical multiple regression analysis were performed to test the third study hypothesis. Substantial support was shown for three-way interaction ( see Table 3). The combination financial responsibility and organizational commitment moderated the relationship between job insecurity and turnover intention $(\beta=.33, P$ $<.01)$. The positive relationship between job insecurity and turnover intention turned out to be weaker under the condition of lower financial responsibility and higher organizational commitment - the regression slop is steeper under that condition (see Fig. 2). Facing a high level of job insecurity, employees with high financial responsibility and low organizational commitment present a greater increase in intention to leave the organization than those with high organizational commitment. Therefore, hypothesis 3 was supported. 
Table 3. Hierarchical regression analysis in predicting turnover intention

\begin{tabular}{|c|c|c|c|c|c|}
\hline & & Step 1 & Step 2 & Step 3 & Step 4 \\
\hline & & Std. $\beta$ & Std. $\beta$ & Std. $\beta$ & Std. $\beta$ \\
\hline \multicolumn{6}{|l|}{ Step 1} \\
\hline & Age & -.10 & -.04 & -.00 & .01 \\
\hline & Edu & -.06 & -.02 & .01 & .03 \\
\hline & Gen & -.05 & -.04 & -.01 & -.00 \\
\hline & $\mathrm{FaM}$ & $-.35 * *$ & $-.25^{* *}$ & $-.25 * *$ & $-.22 * *$ \\
\hline \multicolumn{6}{|l|}{ Step 2} \\
\hline & FiR & & $-.17 *$ & $-.18 *$ & -.15 \\
\hline & OrC & & $-.37 * *$ & $-.45^{* *}$ & $-.33^{* *}$ \\
\hline & JoI & & .30 & $.39 * *$ & $.44 * *$ \\
\hline \multicolumn{6}{|l|}{ Step 3} \\
\hline & $\mathrm{JoI} \times \mathrm{FiR}$ & & & -.12 & -.08 \\
\hline & $\mathrm{JoI} \times \mathrm{OrC}$ & & & -.14 & -.03 \\
\hline & OrC $\times$ FiR & & & $.18^{*}$ & -.03 \\
\hline \multicolumn{6}{|l|}{ Step 4} \\
\hline & $\mathrm{JoI} \times \mathrm{FiR} \times \mathrm{OrC}$ & & & & $-.31 * *$ \\
\hline & $\Delta \mathrm{R}^{2}$ & .14 & .21 & .05 & .04 \\
\hline & $\mathrm{R}^{2}$ & .14 & .35 & .40 & .44 \\
\hline & $\Delta \mathrm{F}$ & $4.16^{* *}$ & $10.40^{* *}$ & $2.33^{*}$ & $6.83 * *$ \\
\hline
\end{tabular}

Note. The results of variance inflation factor (VIF) did not show any problems of multicollinearity. Predictor variables were centered.

$* P<05 ; * * P^{<}<1$

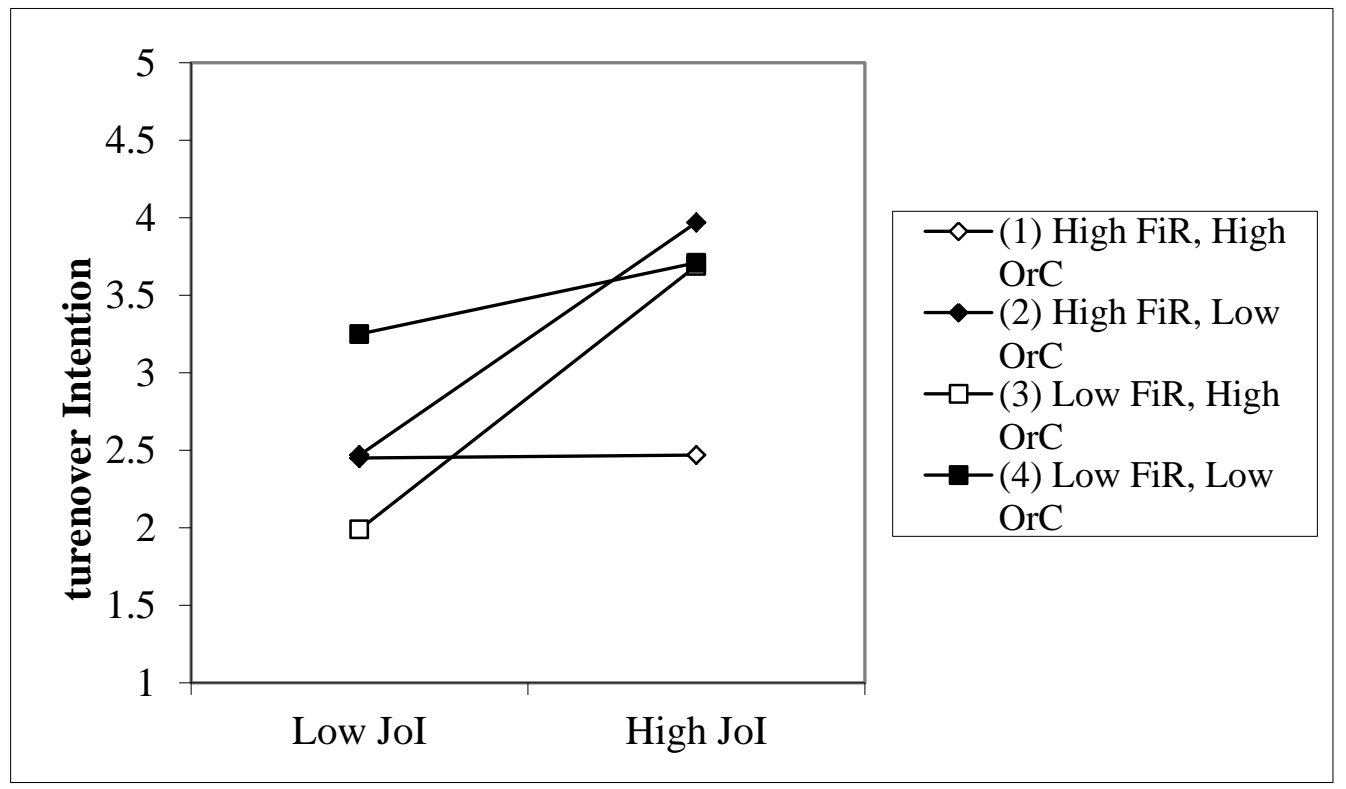

Figure 2. Interaction between JoI, OrC, and FiR in predicting turnover intention

Note. $\mathrm{JoI}=$ job insecurity; $\mathrm{OrC}=$ organizational commitment; $\mathrm{FiR}=$ financial responsibility.

\section{Discussion}

The goals of the present study were to examine the main effect of job insecurity on organizational commitment and turnover intention, as well as the moderating roles of financial responsibility and organizational commitment on the association between job insecurity and turnover intention. The first hypothesis, which stated that there is a significant negative correlation between job insecurity and organizational commitment, was not supported by the 
analysis. This finding is in line with previous studies (De Witte and Näswall, 2003; Guest and Conway, 2000; De Cuyper and De Witte, 2006; De Cuyper, Notelears, and De Witte, 2009). Transactional psychological contract explanations for the results of fixed-contract employees - the sample of the current study - accounted for why this study did not find support for the association between job insecurity and organizational commitment. Psychological contract theory (Rousseau, 1995) postulates that job insecurity effects are because of a violation of the relational psychological contract, hence permanents comparing to temporaries engage more in relational psychological contracting. Job insecurity is likely to be problematic in terms of its outcomes for permanents, but not for temporaries.

The second study hypothesis, which stated that there is a significant positive correlation between job insecurity and turnover intention, was confirmed by the analysis. The result is consistent with previous studies (Lee and Jeong, 2017; Jiménez et al., 2017; Sora, Caballer, and Peiró, 2010; Lebert and Voorpostel, 2016; Çınar, Karcioğlu, and Aslan, 2014; Staufenbiel, and König, 2010; Chirumbolo and Hellgren, 2003). This relationship has been confirmed in Western and non-Western contexts- one of which is the current study.

The third study hypothesis, which stated that there will be three-way interaction between financial responsibility, organizational commitment, and job insecurity in predicting turnover intention, such that employees who feel less commitment to the organization, experience high financial responsibility, and perceive high job insecurity will have a stronger intention to leave the organization, was supported by the analysis. The finding concurs with previous study (Lebert and Voorpostel, 2016; Rigotti, Mohr, and Isaksson, 2015; Sora, Caballer, and Peiró, 2010; Belgley and Czajka, 1993). Job insecurity considers as hindrance stressor, hence organizational commitment protects employees from the negative effects because it allows them to attach direction and meaning to their work (Leong, Furnhan, and Cooper, 1996). In the currrent study, organizational commitment and financial responsibility as moderating variables showed buffering effects on the relationship between job insecurity and intention to leave the organization.

\section{Conclusion}

This study is likely to further debate with regard to the relationship between job insecurity and organizational commitment. The fixed contract type, of employees in the current study, did not need to be problematic regarding psychological outcomes. Fixed- contract employees perceive fewer promises from organizations, i.e. employers than their colleagues on a permanent contract, experiencing less negative effects because they have a narrower but fulfilled contract. They see the two significant psychological features of job insecurity, i.e. unpredictability and uncontrollability unimportant. Therefore, job insecurity does not act as a stressor for these employees concerning organizational commitment. Moreover, another explanation is that fixed-contract employees may want to raise their opportunities to become a permanent contract by showing favorable attitude such as organizational commitment. It is recommended that organizations let their fixed-contract employees know in advance regarding some important entitlements - e.g., job security and advancement in the internal labor market - of their contract type. Hence, they can be more committed to their jobs and have no a spillover effects to life satisfaction and self-rated performance.

Job insecurity triggers an intention to leave an organization. The higher the level of job insecurity, the greater the level of turnover intent. Employees who experience a higher level of job insecurity incline to leave organizations more than those with a lower level of job insecurity. It is believed that the way to cope emotionally with job insecurity as a hindrance stressor - induces undesirable strain reaction - is to use distancing strategies that enable employee to withdraw from the situation in the form of turnover intention. It is recommended that organizations and managers should provide supportive work environment, i.e. from supervisors and colleagues for those employees with fixed-contract so that such negative effects can be mitigated. This support can also be done through clarifying organizational goals and promoting trust among management, following the premises of job demand-resource theory. Another intervention strategy that organizations and managers can implement for alleviating such negative effects is to improve employees' employability through training programs, which, in turn, can give them coping skills to deal with unpleasant feelings generated by job insecurity.

The results of three-way interaction implied that a higher level organizational commitment and a lower level of financial responsibility mitigated the relationship between job insecurity and turnover intention. These two moderating variables play a determinant role in the three-way interaction predicting turnover intention. When employees have a higher level of organizational commitment and a lower level of financial responsibility, their intent to leave the organization became weaker. It is recommended that managers should pay more attention to help employees generate positive attitude through organizational support and organizational justice, which, in turn, resulting in a high level of organizational commitment. Along with that, a lower level of economic need, 
i.e., financial responsibility can be achieved through encouraging on fixed-contract employees to enhance their employability and make more efforts to find other sources of household income.

There are some limitations in the current study that need to be acknowledged and should be addressed as an important avenue for future research. The first limitation is a cross-sectional design, which is not able to determine causal effects. Longitudinal studies would be better suited for causal studies with certain constraints. The second limitation is the possible biases from common methods variance in the self-report measure applied. However, when sample size and reliability of measure are sufficient, true interaction effects are not buried by common methods variance. The third limitation is the data used in the current study were gathered and interpreted by the author, hence increased the probability of overestimating the importance of the examined variables. Different sources, e.g. interview and observation can help overcome this issue. The final limitation is that the current study was limited to fixed-contract employees. Hence, including other types of temporary employees, e.g. on call employees, day-to-day employees, or subcontract employees may introduce more variance in the heterogeneity indicators.

\section{References}

Adebayo, D. O. (2006). The moderating effect of self-efficacy on job insecurity and organizational commitment among Nigerian public servants. Journal of Psychology in Africa, 16(1), 35-43. https://doi.org/10.1080/14330237.2006.10820102

Anderson, C. J., \& Pontusson, J. (2007). Workers, worries and welfare states: Social protection and job insecurity in 15 OECD countries. European Journal of Political Research, 46(2), 211-235. https://doi.org/10.1111/j.1475-6765.2007.00692.x

Becker, H. S. (1960). Notes on the concept of commitment. American journal of Sociology, 66(1), 32-40. https://doi.org/10.1086/222820

Beehr, T. A. (1995). Psychological stress in the workplace. London: Routledge.

Begley, T. M., \& Czajka, J. M. (1993). Panel analysis of the moderating effects of commitment on job satisfaction, intent to quit, and health following organizational change. Journal of Applied Psychology, 78(4), 552-556. https://doi.org/10.1037/0021-9010.78.4.552

Blau, G. (2007). Does a corresponding set of variables for explaining voluntary organizational turnover transfer to explaining voluntary occupational turnover? Journal of Vocational Behavior, 70(1), 135-148. https://doi.org/10.1016/j.jvb.2006.07.007

Blau, P. (1964). Exchange and power in social life. New York: Wiley.

Borg, I., \& Elizur, D. (1992). Job insecurity: Correlates, moderators and measurement. International Journal of manpower, 13(2), 13-26. https://doi.org/10.1108/01437729210010210

Cammann, C., Fichman, M., Jenkins, D., \& Klesh, J. (1979). The Michigan organizational assessment questionnaire. Unpublished manuscript, University of Michigan, Ann Arbor.

Cheng, G. H. L., \& Chan, D. K. S. (2008). Who suffers more from job insecurity? A meta-analytic review. Applied Psychology, 57(2), 272-303. https://doi.org/10.1111/j.1464-0597.2007.00312.x

Chirumbolo, A., \& Areni, A. (2005). The influence of job insecurity on job performance and absenteeism: the moderating effects of work attitudes. SA Journal of Industrial Psychology, 31(4), 65-71. https://doi.org/10.4102/sajip.v31i4.213

Chirumbolo, A., \& Hellgren, J. (2003). Individual and organizational consequences of job insecurity: A European study. Economic and Industrial Democracy, 24(2), 217-240. https://doi.org/10.1177/0143831X03024002004

Çınar, O., Karcıoğlu, F., \& Aslan, İ. (2014). The relationships among organizational cynicism, job insecurity and turnover intention: A survey study in Erzurum/Turkey. Procedia-Social and Behavioral Sciences, 150, 429-437. https://doi.org/10.1016/j.sbspro.2014.09.045

Cohen, J., \& Cohen, P. (1983). Applied multiple regression/correlation analysis for the behavioral sciences. Hillsdale, NJ: Erlbaum.

Cook, J., \& Wall, T. (1980). New work attitude measures of trust, organizational commitment and personal need non-fulfillment. Journal of Occupational and Organizational Psychology, 53(1), 39-52. https://doi.org/10.1111/j.2044-8325.1980.tb00005.x 
Culpepper, R. A. (2011). Three-component commitment and turnover: An examination of temporal aspects. Journal of Vocational Behavior, 79(2), 517-527. https://doi.org/10.1016/j.jvb.2011.03.004

Cuyper, N., \& Witte, H. (2006). The impact of job insecurity and contract type on attitudes, well-being and behavioral reports: a psychological contract perspective. Journal of Occupational and Organizational Psychology, 79(3), 395-409. https://doi.org/10.1348/096317905X53660

Davy, J. A., Kinicki, A. J., \& Scheck, C. L. (1997). A test of job security's direct and mediated effects on withdrawal cognitions. Journal of Organizational Behavior, 323-349. https://doi.org/10.1002/(SICI)1099-1379(199707)18:4<323::AID-JOB801>3.0.CO;2-\#

Dawson, J. F., \& Richter, A. W. (2006). Probing three-way interactions in moderated multiple regression: Development and application of a slope difference test. Journal of Applied Psychology, 91, 917-926. https://doi.org/10.1037/0021-9010.91.4.917

De Cuyper, N., Notelaers, G., \& De Witte, H. (2009). Job insecurity and employability in fixed-term contractors, agency workers, and permanent workers: Associations with job satisfaction and affective organizational commitment. Journal of Occupational Health Psychology, 14(2), 193. https://doi.org/10.1037/a0014603

De Witte, H. (2000). Work ethic and job insecurity: Assessment and consequences for well-being, satisfaction and performance at work. From group to community, 325-350.

De Witte, H., and Näswall, K. (2003). Objective'vs subjective'job insecurity: Consequences of temporary work for job satisfaction and organizational commitment in four European countries. Economic and industrial democracy, 24(2), 149-188. https://doi.org/10.1177/0143831X03024002002

De Witte, H., Pienaar, J., \& De Cuyper, N. (2016). Review of 30 Years of Longitudinal Studies on the Association Between Job Insecurity and Health and Well-Being: Is There Causal Evidence?. Australian Psychologist, 51(1), 18-31. https://doi.org/10.1111/ap.12176

Direnzo, M. S., \& Greenhaus, J. H. (2011). Job search and voluntary turnover in a boundaryless world: A control theory perspective. Academy of Management Review, 36(3), 567-589.

Erlinghagen, M. (2007). Self-perceived job insecurity and social context: A multi-level analysis of 17 European countries. European Sociological Review, 24(2), 183-197. https://doi.org/10.1093/esr/jcm042

Ertureten, A., Cemalcilar, Z., \& Aycan, Z. (2013). The relationship of downward mobbing with leadership style and organizational attitudes. Journal of Business Ethics, 116(1), 205-216. https://doi.org/10.1007/s10551-012-1468-2

Greenhalgh, L., \& Rosenblatt, Z. (1984). Job insecurity: Toward conceptual clarity. Academy of Management review, 9(3), 438-448. https://doi.org/10.5465/amr.1984.4279673

Greenhalgh, L., \& Rosenblatt, Z. (2010). Evolution of research on job insecurity. International Studies of Management \& Organization, 40(1), 6-19. https://doi.org/10.2753/IMO0020-8825400101

Guest, D., \& Conway, R. (2000). The public sector and the psychological contract. IPD Research Report. London: IPD.

Hellgren, J., Sverke, M., \& Isaksson, K. (1999). A two-dimensional approach to job insecurity: Consequences for employee attitudes and well-being. European Journal of Work and Organizational Psychology, 8(2), 179-195. https://doi.org/10.1080/135943299398311

Hobfoll, S. E. (1989). Conservation of resources: A new attempt at conceptualizing stress. American psychologist, 44(3), 513- 524. https://doi.org/10.1037/0003-066X.44.3.513

Hoffmeyer-Zlotnik, J. H., \& Warner, U. (1998). Die Messung von Einkommen im nationalen und internationalen Vergleich. Zuma Nachrichten, 22(42), 30-65.

Houkes, I., Janssen, P. P., Jonge, J., \& Bakker, A. B. (2003). Specific determinants of intrinsic work motivation, emotional exhaustion and turnover intention: a multisampling longitudinal study. Journal of Occupational and Organizational Psychology, 76(4), 427-450. https://doi.org/10.1348/096317903322591578

$\mathrm{Hu}$, Q., \& Schaufeli, W. B. (2011). Job insecurity and remuneration in Chinese family-owned business workers. Career Development International, 16(1), 6-19. https://doi.org/10.1108/13620431111107784

Hulin, C. (1991). Adaptation, Persistence, and Commitment in Organizations. In Dunnette, M.D. and Hough, L.M. (eds.), Handbook of Industrial and Organizational Psychology, 2, 2nd edn. PaloAlto, CA: Consulting Psychologists Press, 445-505. 
Hur, H., \& Perry JI. (2014). The relationship between job security and work attitudes: a meta-analysis examine competing theoretical models. Paper presented at American Political Science Association, Washington, DC. https://doi.org/10.2139/ssrn.2452082

Jiménez, P., Milfelner, B., Žižek, S. Š., \& Dunkl, A. (2017). Moderating effects between job insecurity and intention to quit in samples of Slovene and Austrian workers. Naše gospodarstvo/Our economy, 63(1), 27-37. https://doi.org/10.1515/ngoe-2017-0003

Låstad, L., Vander Elst, T., \& De Witte, H. (2016). On the reciprocal relationship between individual job insecurity and job insecurity climate. Career Development International, 21(3), 246-261. https://doi.org/10.1108/CDI-03-2015-0046

Lazarus, R. S., \& Folkman, S. (1984), Stress, Appraisal, and Coping, Springer, New York, NY.

Lebert, F., \& Voorpostel, M. (2016). Turnover as a strategy to escape job insecurity: The role of family determinants in dual-earner couples. Journal of Family and Economic Issues, 37(3), 407-421. https://doi.org/10.1007/s10834-016-9498-Z

Lee, S. H., \& Jeong, D. Y. (2017). Job insecurity and turnover intention: Organizational commitment as mediator. Social Behavior and Personality: an international journal, 45(4), 529-536. https://doi.org/10.2224/sbp.5865

Leka, S., Jain, A., \& World Health Organization. (2010). Health impact of psychosocial hazards at work: an overview.

Leong, C. S., Furnham, A., \& Cooper, C. L. (1996). The moderating effect of organizational commitment on the occupational stress outcome relationship. Human relations, 49(10), 1345-1363. https://doi.org/10.1177/001872679604901004

Lin, C. P., Tsai, Y. H., \& Mahatma, F. (2017). Understanding turnover intention in cross-country business management. Personnel Review, 46(8), 1717-1737. https://doi.org/10.1108/PR-07-2016-0176

Lübke, C., \& Erlinghagen, M. (2014). Self-perceived job insecurity across Europe over time: Does changing context matter?. Journal of European Social Policy, 24(4), 319-336. https://doi.org/10.1177/0958928714538215

Lutgen-Sandvik, P., Hood, J. N., \& Jacobson, R. P. (2016). The impact of positive organizational phenomena and workplace bullying on individual outcomes. Journal of Managerial Issues, 28(1/2), 30-49.

Meyer, J. P., \& Allen, N. J. (1991). A three-component conceptualization of organizational commitment. Human resource management review, l(1), 61-89. https://doi.org/10.1016/1053-4822(91)90011-Z

Meyer, J. P., Allen, N. J., \& Smith, C. A. (1993). Commitment to organizations and occupations: Extension and test of a three-component conceptualization. Journal of applied psychology, 78(4), 538. https://doi.org/10.1037/0021-9010.78.4.538

Meyer, J. P., Stanley, D. J., Herscovitch, L., \& Topolnytsky, L. (2002). Affective, continuance, and normative commitment to the organization: Meta-analysis of antecedents, correlates, and consequences. Journal of Vocational Behavior, 61, 20-52. https://doi.org/10.1006/jvbe.2001.1842

Mobley, W. H. (1977). Intermediate linkages in the relationship between job satisfaction and employee turnover. Journal of applied psychology, 62(2), 237. https://doi.org/10.1037/0021-9010.62.2.237

Mowday, R., Steers, R., \& Porter, L. (1979). The measurement of organizational commitment. Journal of Vocational Behavior, 14(2), 224-247. https://doi.org/10.1016/0001-8791(79)90072-1

Pienaar, J., De Witte, H., Hellgren, J., \& Sverke, M. (2013). The cognitive/affective distinction of job insecurity: Validation and differential relations. Southern African Business Review, 17(2), 1-22.

Podsakoff, N. P., LePine, J. A., \& LePine, M. A. (2007). Differential challenge stressor-hindrance stressor relationships with job attitudes, turnover intentions, turnover, and withdrawal behavior: a meta-analysis. Journal of applied psychology, 92(2), 438. https://doi.org/10.1037/0021-9010.92.2.438

Powell, D. M., \& Meyer, J. P. (2004). Side-bet theory and the three-component model of organizational commitment. Journal of vocational behavior, 65(1), 157-177. https://doi.org/10.1016/S0001-8791(03)00050-2

Probst, T. M. (2000). Wedded to the job: Moderating effects of job involvement on the consequences of job insecurity. Journal of Occupational Health Psychology, 5, 63-73. https://doi.org/10.1037/1076-8998.5.1.63

Probst, T. M. (2002). The impact of job insecurity on employee work attitudes, job adaptation, and 
organizational withdrawal behaviors. In J.M. Brett \& F. Drasgow (Eds.), The psychology of work: Theoretically based empirical research (pp. 141-168). Mahwah, NJ: Lawrence Erlbaum Associates.

Rigotti, T., Mohr, G., \& Isaksson, K. (2015). Job insecurity among temporary workers: Looking through the gender lens. Economic and Industrial Democracy, 36(3), 523-547. https://doi.org/10.1177/0143831X13516026

Rosenblatt, Z., Talmud, I., \& Ruvio, A. (1999). A gender-based framework of the experience of job insecurity and its effects on work attitudes. European Journal of work and organizational psychology, 8(2), 197-217. https://doi.org/10.1080/135943299398320

Rousseau, D. M. (1995). Psychological contracts in organizations: Understanding written and unwritten agreements. Thousand Oaks, CA: Sage.

Saudi Arabia Labor Market Report. (2016). Ministry of Labor \& Social Development.

Schaufeli, W. B. (2016). Heavy work investment, personality and organizational climate. Journal of Managerial Psychology, 31(6), 1057-1073. https://doi.org/10.1108/JMP-07-2015-0259

Schaufeli, W. B., \& Taris, T. W. (2014). A critical review of the Job Demands-Resources Model: Implications for improving work and health. In Bridging occupational, organizational and public health (pp. 43-68). Springer Netherlands. https://doi.org/10.1007/978-94-007-5640-3_4

Shoss, M. K. (2017). Job insecurity: An integrative review and agenda for future research. Journal of Management, 43(6), 1911-1939. https://doi.org/10.1177/0149206317691574

Sinclair, R. R., and Cheung, J. H. (2016). Money matters: Recommendations for financial stress research in occupational health psychology. Stress and Health, 32(3), 181-193. https://doi.org/10.1002/smi.2688

Solinger, O. N., Van Olffen, W., \& Roe, R. A. (2008). Beyond the three-component model of organizational commitment. Journal of applied psychology, 93(1), 70-83. https://doi.org/10.1037/0021-9010.93.1.70

Sora, B., Caballer, A., \& Peiró, J. M. (2010). The consequences of job insecurity for employees: The moderator role of job dependence. International Labour Review, 149(1), 59-72. https://doi.org/10.1111/j.1564-913X.2010.00075.x

Starr, M. A. (2014). Gender, added-worker effects, and the 2007-2009 recession: Looking within the household. Review of Economics of the Household, 12(2), 209-235. https://doi.org/10.1007/s11150-013-9181-1

Staufenbiel, T., \& König, C. J. (2010). A model for the effects of job insecurity on performance, turnover intention, and absenteeism. Journal of Occupational and Organizational Psychology, 83(1), 101-117. https://doi.org/10.1348/096317908X401912

Sverke, M., Hellgren, J., \& Näswall, K. (2002). No security: a meta-analysis and review of job insecurity and its $\begin{array}{llllll}\text { consequences. Journal of occupational health psychology, } & 7(3), & 242 .\end{array}$ https://doi.org/10.1037/1076-8998.7.3.242

Sverke, M., Hellgren, J., \& Näswall, K. (2006). Job Insecurity. A Literature Review. (Report 1) Stockholm: National Institute For Working Life.

Tschopp, C., \& Grote, G. (2014). The How and Why of the Relationship Between Job Insecurity, Subjective Career Success, and Turnover Intention. In Psychological, Educational, and Sociological Perspectives on Success and Well-Being in Career Development (pp. 127-150). Springer, Dordrecht. https://doi.org/10.1007/978-94-017-8911-0_7

Van Vuuren, T., Klandermans, B., Jacobson, D., \& Hartley, J. (1991). Employees' reactions to job insecurity. In Hartley, J., Jacobson, D., Klandermans, B., Van Vuuren, T. (Eds.), Job insecurity: Coping with jobs at risk: 79-103. London: Sage.

Vujičić, D., Jovičić, A., Lalić, D., Gagić, S., \& Cvejanov, A. (2015). The relation between job insecurity, job satisfaction and organizational commitment among employees in the tourism sector in Novi Sad. Economic and Industrial Democracy, 36(4), 633-652. https://doi.org/10.1177/0143831X14527017

Werner, O., \& Campbell, D. T. (1970). Translating, working through interpreters, and the problem of decentering. A handbook of method in cultural anthropology, 398, 420.

Witte, H. D. (1999). Job insecurity and psychological well-being: Review of the literature and exploration of some unresolved issues. European Journal of work and Organizational psychology, 8(2), 155-177. https://doi.org/10.1080/135943299398302 
Wu, A. D., \& Zumbo, B. D. (2008). Understanding and using mediators and moderators. Social Indicators Research, 87(3), 367. https://doi.org/10.1007/s11205-007-9143-1

\section{Copyrights}

Copyright for this article is retained by the author(s), with first publication rights granted to the journal.

This is an open-access article distributed under the terms and conditions of the Creative Commons Attribution license (http://creativecommons.org/licenses/by/4.0/). 